\section{Injury and illness surveillance in sports: how golf, tennis, cycling and parasport extended the IOC consensus statement to tailor injury and illness surveillance to specific sports}

\author{
Jiri Dvorak (ㄷ, ' Babette M Pluim (1) 2,3,4
}

For a sport to develop a meaningful injury prevention strategy, sound epidemiological data are crucial. This, in turn, needs to be based on the analysis of known risk factors involved in the sport so that mitigation strategies can be introduced by modifying the rules and laws if necessary. The key objective for medical advisors in sports is to reduce morbidity and to promote the sport as a health-enhancing leisure activity. ${ }^{1}$ In this editorial, we aimed to motivate other international sport federations to take similar action.

Insufficient physical activity greatly increases the risk of non-communicable diseases, and physical inactivity is one of the biggest public health threats of the 21st century. $^{2}$

Despite the incontrovertible evidence of the health benefits of physical activity, a WHO survey of 1.6 million participants in 146 countries revealed that $81 \%$ of children and adolescents aged 11-17 years participated in insufficient physical activity. ${ }^{3}$ In a climate dominated by COVID-19, obesity is clearly linked to poor outcome, along with a number of other comorbidities that have been proven to be mitigated by exercise (high blood pressure, cardiovascular conditions and diabetes).

The very wide diversity of team and individual sports means injuries in particular (less so illness) vary enormously. So some form of standardisation of injury capture is essential, if the data from injury and illness surveillance are going to be meaningful. Researchers

\footnotetext{
${ }^{1}$ Swiss Golf Medical Centre, Spine Unit, Schulthess Clinic, Zurich, Switzerland

${ }^{2}$ Section Sports Medicine, University of Pretoria, Faculty of Health Sciences, Pretoria, South Africa

${ }^{3} \mathrm{AMC} / \mathrm{VUmc}$ IOC Research Center of Excellence, Amsterdam Collaboration on Health \& Safety in Sports (ACHSS), Amsterdam, The Netherlands

${ }^{4}$ Medical Dept, Royal Dutch Lawn Tennis Association (KNLTB), Amstelveen, The Netherlands
}

Correspondence to Professor Babette M Pluim, Royal Dutch Lawn Tennis Association, Amstelveen, The Netherlands; b.pluim@knltb.nl need to use standard definitions for injuries, time loss, injury burden and exposure. In this regard, the 'IOC Consensus Statement: Methods for Recording and Reporting Data on Injury and Illness in Sports 2020' is a true landmark. ${ }^{4}$ It provides a blueprint for sports to follow and has been used to produce the consensus statements for golf, tennis, cycling and parasport. ${ }^{5-7}$

\section{WHICH SPORT-SPECIFIC DATA ARE NEEDED?}

The main areas where the 4 sports we focus on here have extended the IOC consensus statement are: describing the study population, reporting training and match exposure, and expressing risk. In golf, exposure can be measured by time, number of holes played, or number of balls hit (driving range), and injuries can be expressed by 1000 hours, 1000 holes played, or by 1000 balls hit. In tennis, one can record training and match exposure in hours or in games, sets or matches. Technology-optical tracking systems and inertial measurement unit (IMU) sensors -have made it easy to break tennis down even further into specific load: number and velocity of strokes, and accelerations, changes of direction, and distance covered.

Specific to parasport are the body areas that may be injured in amputees, baseline information on impairment, and impairment-specific tissue and pathology types for injuries (eg, phantom pain, hypertonia, pressure ulcers). The paper contains a table that suggests measures of exposure for the various para sport disciplines.

Typical exposure measures for cycling come from portable power meters attached to the bike. In combination with global positioning systems and heart rate monitors, one can use software to collect information on power output, distance covered, aerobic training load, training stress score and other load measures. Wearable IMU sensors provide information on angular velocity, acceleration, and jumps.

\section{BUILDING ON SOLID FOUNDATIONS}

The idea of standardised injury surveillance is not new, and the origins of the IOC consensus statement can be traced back to groundbreaking studies undertaken by the Fédération Internationale de Football (FIFA), the Fédération Internationale de Natation (FINA), the International Association of Athletics Federations (IAAF), and by the IOC at Summer and Winter Olympic Games. ${ }^{8}$ 910 Going forward, this 2020 IOC Consensus Statement provides the foundation for the new injury and illness classification for golf, ${ }^{5}$ tennis, ${ }^{6}$ parasport, ${ }^{7}$ and cycling. With 87000000 people playing tennis and 60000000 playing golf, these sports rate in the top 10 of global popularity.

With a standardised reporting system, as outlined by the IOC in its 2020 Consensus Statement, ${ }^{4}$ researchers will now be able to analyse the incidence and prevalence of injuries and make valid comparisons among sports. The sport-specific extensions of the IOC consensus statement may also serve as examples for other international sports federations. This helps to harmonize the surveillance of injury and illness across sports and it will promote the healthenhancing aspects of physical activity.

Twitter Jiri Dvorak @ProfJiriDvorak and Babette M Pluim @docpluim

Acknowledgements The authors thank Astrid Junge for spending more than 20 years helping them with the epidemiology of injury surveillance and Andrew Murray for promoting the concept in golf.

Contributors JD drafted the initial version of this article and BMP modified the subsequent versions. Both authors approved the final version of the manuscript.

Funding The authors have not declared a specific grant for this research from any funding agency in the public, commercial or not-for-profit sectors.

Competing interests BMP is a member of the Sport Science and Medicine Commission of the International Tennis Federation and chief medical adviser of the Royal Dutch Lawn Tennis Association.

Patient consent for publication Not required.

Provenance and peer review Not commissioned; externally peer reviewed.

(c) Author(s) (or their employer(s)) 2021. No commercial re-use. See rights and permissions. Published by BMJ.

$$
\text { (D) Check for updates }
$$

To cite Dvorak J, Pluim BM. Br J Sports Med 2021;55:1-5.

Accepted 6 October 2020

Published Online First 29 October 2020 
Br J Sports Med 2021;55:1-5.

doi:10.1136/bjsports-2020-102616

\section{ORCID iDs}

Jiri Dvorak http://orcid.org/0000-0002-2178-2326 Babette M Pluim http://orcid.org/0000-0003-06558980

\section{REFERENCES}

1 Dvorák J. Give Hippocrates a Jersey: promoting health through football/sport. Br J Sports Med 2009;43:31722.

2 Blair SN. Physical inactivity: the biggest public health problem of the 21 st century. Br J Sports Med 2009;43:1c.

3 Guthold R, Stevens GA, Riley LM, et al. Global trends in insufficient physical activity among adolescents: a pooled analysis of 298 population-based surveys with 1.6 million participants. Lancet Child Adolesc Health 2020;4:23-35.

4 Bahr R, Clarsen B, Derman W, et al. International Olympic Committee consensus statement: methods for recording and reporting of epidemiological data on injury and illness in sport 2020 (including STROBE extension for sport injury and illness surveillance (STROBE-SIIS)). Br J Sports Med 2020:54:372-89.

5 Murray A, Junge A, Robinson PG, et al. International consensus statement: methods for recording and reporting of epidemiological data on injuries and illnesses in golf. Br J Sports Med 2020;54:113641.

6 Verhagen E, Benjamin C, Capel-Davies J, et al. Tennis-specific extension of the International Olympic Committee consensus statement - methods for recording and reporting of epidemiological data on injury and illness in sport 2020. Br J Sports Med 2020.

7 Derman W, Badenhorst M, Blauwet CA, et al. Para sport translation of the $I O C$ consensus statement on the recording and reporting of data for injury and illness in sport. Br J Sports Med.

8 Junge A, Dvorak J. Influence of definition and data collection on the incidence of injuries in football. $\mathrm{Am} J$ Sports Med 2000;28:40-6.

9 Dvorak J, Junge A, Chomiak J, et al. Risk factor analysis for injuries in football players. possibilities for a prevention program. Am J Sports Med 2000;28:S6974.

10 Junge A, Engebretsen L, Alonso JM, et al. Injury surveillance in multi-sport events: the International Olympic Committee approach. Br J Sports Med 2008:42:413-21. 